\title{
Corporate Governance and Earnings Management: A Model and Empirical Investigation from Karachi Stock Exchange
}

\author{
Marina Afzal * $\quad$ Muhammad Danish Habib ${ }^{\dagger}$
}

\begin{abstract}
This study seeks to probe into the relationship between Corporate Governance (CG) and Earnings Management (EM). To fulfill the objective of the study, a panel data approach by considering the data of seventy four (74) non-financial firms listed at Karachi Stock Exchange (KSE) for the time period of nine years from 2005 to 2013 have been taken. Earnings management is calculated through discretionary accruals as a proxy by using Modified Jones Model. Panel data is analyzed for correlation analysis, assumptions of regression and Random-effects GLS regression by using STATA 13. In general results are in favor of the propositions that effective corporate governance polices restrict EM practices. The empirical findings of the present paper contain some relevant policy implications.
\end{abstract}

Keywords: Financial reporting, audit committee, corporate governance, capital structure, dividend policy, earnings management.

\section{Introduction}

Earnings quality is one of the fundamental concepts in financial economics as well as accounting literature. A plethora of literature and a number of accounting debates at international forums have focused on the earnings quality and for setting high quality standards for reporting of earnings (Levitt, 1998). Earnings Management (EM) practices can take numerous forms such as, accruals management; altering accounting measures; and structuring certain transactions, expenses, and revenues. It is considered as legal if documented earnings are modified as per generally accepted accounting principles (GAAP), for instance, modification in the procedure for depreciation and inventory estimation. However, it becomes fraudulent, when it goes beyond GAAP, for example, accelerating income acknowledgment (C. Y. Yang, Lai, \& Leing, 2008). Regardless of the immense interest shown by different researchers in this area of study, there is no consensus on the definition of EM (Beneish, 2001). However, a widely accepted definition by Healy and Wahlen (1999) is that EM is a mechanism in which managers use their discretion while reporting financial information to manipulate contractual outcomes or economic performance of the firm and to deceive the stakeholders. It is the demand of the recent time span to further explore the relationship between corporate governance and earnings management (Bao \& Lewellyn, 2017; Braswell \& Daniels, 2017).

*PhD Scholar, School of Business and Management Sciences. University of Gujrat, Pakistan. Email: marinaafzal@ymail.com

${ }^{\dagger}$ PhD Scholar, Department of Management Sciences, SZABIST, Islamabad, Pakistan. Email: danish.habib87@gmail.com 
The current study models and empirically tests the panel data for nine years from 2005 to 2013 for seventy-four (74) non-financial listed firms at Karachi Stock Exchange (KSE) using Modified Jones Model. This study extends the growing literature of EM by examining the causal inference between EM and corporate governance (CG). Particularly, this research takes into account the key contributing proxies of corporate governance and examines their role in restricting EM practices. Although, research studies on corporate governance and earnings management relationship present quite impressive and fertile results. However, scholars highlighted the importance of the audit committee (Swastika, 2013; Zhao, Chen, Zhang, \& Davis, 2012; Raza \& Karim, 2016) in earnings management. First, it is believed that the audit committee in Pakistan are not as independent as a good corporate governance culture would demand (Azeem, Hassan, \& Kouser, 2013). The independence of the audit committee has a fundamental role on the quality of the audit (Zhao et al., 2012). So the empirical findings may be helpful for the better understanding of the role of independence of the audit committee for audit quality that ultimately restricts EM practices. The findings of the research are helpful for developing a clearer perception of investors regarding the role of different contributing factors in the financial reporting process and the misrepresentation of earnings. Measuring the effect of these contributing factors allows the investors to be mindful regarding opportunistic purposes and management's capacity to manipulate earnings in its own interest. Therefore, the results of this study provide a solid ground for investors to remove uncertainty by identify possibilities of opportunistic purposes and improve their decision-making process.

\section{Literature Review}

\section{Corporate Governance and Earnings Management}

Corporate governance (CG) is a set of principles developed and implemented by institutions for the protection of firms from opportunistic behavior (Shleifer \& Vishny, 1997; Gillan, 2006). CG is defined as the mechanisms of rules, laws, and principles for managing control in an organization (Gillian \& Starks, 1998). Governance is considered as indicators of a firm's performance. Better governance has a significantly positive influence on a firm's performance. Good governance ensures the effective and efficient utilization of organizational resources and minimizes the exploitation by controlling authority in an opportunistic way. As effective governance protects the rights of investors, so they feel secure about their investments. Effective governance also minimizes agency problems by restricting the discretionary behavior of management and controlling authority. Regardless of investors, other stakeholders like employees and suppliers are attracted towards the firms with good governance systems. Extant literature exists exploring the relationship between EM and corporate governance. Recent literature on EM acknowledges corporate governance as a determinant of EM and also provides empirical evidence of a significantly positive association between these two concepts (Dechow, Sloan, \& Sweeney, 1996; Beasley, 1996). A plethora of literature documented that weak governance mechanism allows for manipulation of earnings in an opportunistic way. 
In a research study, Beasley (1996) argued that if the board of directors is independent and saturated by outside members then chances of earnings management practices becomes lesser. Jesus and Emma (2013) examine the association between different proxies of CG (board independence, institutional investors, ownership concentration and insider shareholding) and EM. The results of the study revealed a significant negative relationship between board activity and EM. It is documented that if the number of board meetings is regular, it is an indication of an active board, and is helpful in restricting EM practices.

Furthermore, results showed that board size and family ownership has a significantly positive impact on EM. Several empirical studies have argued that family owned firms have weak corporate governance systems and are more inclined towards EM practices. Similarly, the concentration of power to a controlling authority may also result in increased EM practices. Bugshan (2005) stated that firms belonging from countries where strong governability systems are implemented are less involved in EM practices. Liu and Lu (2007) explored the systematic differences in EM practices by using the data of listed firms on China's stock exchange for the period of 1999-2005. The empirical findings showed that if firms have a higher level of governance systems then the chances of EM practices are significantly lower. A plethora of literature highlighted the importance of governance systems and reported that if effective methods are developed to restrict managers to use organizational resources for their opportunistic behavior then it will be helpful for reducing the agency problem as well as EM practices. Berry, Fields, and Wilkins (2006) found that independence can be increased by using a dual management structure which resulted in preventing EM practices and increasing firms' performance by achieving stakeholder trust.

\section{Hypothesis Development}

\section{Institutional Ownership and Earnings Management}

The literature on institutional ownership demonstrates that institutional investors have sophisticated investment behavior, which usually has a monitoring role to reduce the pressure for myopic behavior. Institutional investors are more concerned to collect information regarding the firm in which they are interested to invest or they have invested. Large ownership probably leads to the urge the institution to become an active observer for relevant policy decisions and the identification of manipulation in earnings. Literature explores the determinants of EM by using institutional ownership under two schools of thoughts.

First view proposes that institutional investors have both the inducement and authority to control and limit the opportunistic behavior of executives prevailing as EM practices. The second view argues that short-term returns are the primary concern of the institutional investors so they are not too much interested in controlling management. Institutional investors may sell their stakes and then remove or monitor the incompetent management. First view as on institutional ownership claimed that monitoring by us- 
ing institutional ownership may be considered as a fundamental governance mechanism. Lefort and Walker (2005) pointed out that, institutional investors play an important role in designing corporate governance policies of companies. Institutional ownership is an important precursor of corporate behavior, as higher institutional ownership has a positive influence on corporate behavior.

The second point of view claimed institutional investors as myopic or transient having short term orientation. Such investors mainly focus on short term current earning and are less concerned about long term earnings (Bushee, 2001). They are very active in monitoring the activities of management, they sell their shares if they observe any amiss (Coffee, 2002). W. S. Yang, Chun, and Shamsher (2009) studied the role of institutional shareholders and external directors in confining the activities of EM using the data of Malaysian companies. The finding revealed a statistically insignificant relationship between institutional ownership and EM.

However, Ebrahim (2007) examined the causal relation between institutional investors and EM considering the data of 700 listed companies on Tehran Stock Exchange for the period of five years from 2006 to 2010. The results revealed a positive significant relationship between institutional investors and EM. So this stated that as institutional share holders ownership level increases the possibility of EM also increases. Based on the literature discussed above, the following hypothesis can be formulated as:

\section{H1a: There is a negative relation between institutional ownership and EM.}

\section{Managerial Ownership and Earnings Management}

Managerial ownership is one of the fundamental stimuli to motivate managers to act actively for the value of the firm. Claessens, Djankov, and $\mathrm{Xu}$ (2000) developed the proposition that conflict can be reduced by employee stock option or ownership, as it will align the interest of stockholders and managers.

Contrary to this, Stulz (1988) stated entrenchment proposition as ownership of managers beyond a certain level may provide a chance to managers to exploit the rights of external minority shareholders. While studying the relationship between EM and managerial ownership, Teshima and Shuto (2008) also developed a theoretical framework and claimed that EM practices are lower when managerial ownership is either high or low but when managerial ownership is at an intermediate level then activities regarding EM are high. Consequently, a non-linear but cubical relationship exists between managerial ownership and EM.

However, L. Chen and Zhang (2007) asserted that increase in executive ownership share lead towards higher incentive to manipulate earnings. They recommended that there should be some conditions and limitations placed on managerial ownership level to avoid the activities regarding the manipulation of earnings. Ebrahim (2007) also argued that managerial ownership is an effective mechanism for monitoring specifically in small firms. Contrary to prior research studies, Sánchez-Ballesta and García-Meca (2007) examined the association among informativeness of earnings, discretionary accruals, and ownership structure by using panel data approach for the non-financial Spanish firm for 
the period of 1999-2002. The results showed a nonlinear relationship between earnings explanatory power for returns and insider ownership. C. Y. Yang et al. (2008) found a significantly positive association between managerial ownership and EM on firms listed on Taiwanese Stock by using data for the period of 1997-2004. In contrast with this, Gulzar (2011) documented a negatively statistically significant impact of managerial ownership and EM. Thus, the literature revealed mixed results concerning managerial ownership and EM. So it can be proposed that:

H1b: There is a negative relation between managerial ownership and EM.

\section{Board Size and Earnings Management}

Board size is an important element in the characteristics of a board which may influence earning management practices. Board size is an indication of the total number of nonexecutives and executives directors of the board. There are least chances for the company management's dominance if the board size is larger. Moreover, larger board size renders diversity of expertise, both in managerial and financial terms in the board (Laksmana, Tietz, \& Yang, 2012). Kao and Chen (2004) explore the relationship between EM and board size and found that the higher board size causes a greater extent of earning management.

Previous research studies also support the argument of the significant contribution of board size in increased the disclosure level and representing a significant relationship between the level of firm's disclosure and board size (Barako, Hancock, \& Izan, 2006). Monks and Minow (2012), validating the findings of Lipton and Lorsch (1992) proposed that the board with larger size requires more efforts and time to oversee management as compared to smaller boards. Klein (2002) also validated this argument and extend it by proposing that board size is positively related to board monitoring as they can distribute the work over a larger number of the observer. Habbash (2010) confirmed the result that larger board is more likely to restrict earning management by using 471 UK firms taking the data from 2003 to 2006.

Furthermore, a plethora of literature confirms this argument by depicting an inverse association between board size and EM (Peasnell, Pope, \& Young, 2005; Yu, 2008). Yermack (1996) and Goodstein, Gautam, and Boeker (1994) suggested that a smaller board size composed of four to six members have the ability to monitor management activities as well as taking effective decisions. Xie, Davidson III, and DaDalt (2003) study board characteristics in developing EM with the help of discretionary current accruals. The results revealed that firm with a larger board size is less likely to perform EMs. Yu (2008) reported that boards with smaller size are more likely to suffer from the failure to detect EM. Zahra and Pearce (1989), argued that a smaller board may be dominated or get influenced by the block holder or more likely to controlled by the management.

The boards with larger size can supervise management in an effective way and settle on quality corporate decisions. Many researchers found an inverse impact of board size and EM practices, elaborating that if the board size is larger than there are fewer chances of manipulative practices performed by the management of a company. Contrary to the aforementioned results, De Andrés-Alonso, Cruz, and Romero-Merino (2006) proposed 
that if the board size is larger than there will be poorer communication and coordination between members of boards, this results in a positive significant association between EM and board size. However, the findings of this study cannot be generalized due to several limitations. First, the findings of the study were inconsistent and based only on one year data. Second, study results may be biased as this study uses mix data sample from different countries without controlling the external factors like regulatory rules, accounting standards. There are contrary and uncertain findings between board size and EM, whether there is a positive or negative association between board size and earning management. There is no need to criticize the direction of the relationship as both points of view are logically acceptable and justified by the help of past researches. Thus on the basis of the above mention literature, it can be proposed that:

H1c: There is a negative relation between board size and EM.

\section{Board Activity / Board Meeting and Earnings Management}

Board activity is an important characteristic associated to the board of directors, representing the number of meetings throughout its composition (independence and size) are necessary Chan, Lin, and Zhang (2007) and Chekili (2012) recommended, board acts as an important proxy for the monitoring of directors activity and performance. Frequent meeting of the board of directors' assist the directors to design their duties according to the interest of shareholders' interests and spend more time to scrutinize the issues like inspection of management, conflicts of interest and EM.

Contrary to this, a lesser amount of board meetings may not figure out the complex issues and spend their time in approval of management plans. Xie et al. (2003) proposed that if the board has a less frequent meeting they have not sufficient time for focusing issues like earning management. Xie et al. (2003) studying a sample of 282 found an inverse relationship between the number of board meetings and EMs. Lin and Hwang (2010) identified that for a better and effective monitoring of management frequent meetings are required. Boards that meet few times or do not meet are considerably ineffective monitors. Furthermore, they extend their argument that the board should be active and comprehend their task as a continuous process.

The past literature documented a non-significant relationship between EMs and board meetings. Habbash (2010) by comparing different sample over a different period of time concluded that board activity may not limit the practices of EM. Habbash (2010) argued that the frequency of meeting may not be considered as the characteristics of an active board. In a research survey Adams and Ferreira (2009) explore the role of outside directors as monitor and monitors of management. Adams and Ferreira (2009) argued directors who have dominance on management control have the perception to participate less as compared to other directors and that the CEO often asks them for advice. Based on the literature discussed above, the following hypothesis can be formulated as:

H1d: There is a negative relation between board meetings and EM. 


\section{CEO / Chair Duality and Earnings Management}

Duality is a situation in which Chief Executive Officer (CEO) also having the authority of the chairman of the board of directors. This body has the powers to appoint, dismiss and pay the CEO as well as to monitor and rectify the higher level decisions. Fama and Jensen (1983) are with the view point that board of directors can be utilized as an effective tool for control over management if and only if it can influence and limit the discretionary behavior of managers. On the bases of this point of view, Fama and Jensen (1983) argue that distinction between control function and state that management plays a fundamental role in reducing agency cost.

The dual role of chairman and CEO appears as a barrier to the division between the control function and management. Jensen (1993) claimed that it became complicated for a board to regulate a CEO having charge of chairman of the board. So, Jensen (1993) recommended that these two functions should be separated. The firms having the same person as $\mathrm{CEO}$ and chairman are more liable for lower financial reporting as to achieve his own interest CEO may manipulate the financial reporting. In the majority (75\%) of misrepresentation of financial reporting, they identified a single person who holds over the firm's financial as well as operating decisions. Patton (1990) argue that the dual authority of a person causes the development CEO dominate board.

With the viewpoint of agency theory, the board chair should be independent as CEO handed with undue authorities may incline more towards misrepresented or manipulated EM. Literature has documented that duality function in a firm may hinder a management to perform their function and operations properly and freely. Klein (2002) using the Jones (1991), found a significantly positive impact of CEO duality (compensation committee and the board's nominating) on discretionary accruals. His finding recommends that CEO with excessive powers have greater influence overboard and can easily manage earrings. Moreover, Kaymak and Bektas (2008), based on the data from 2001-2004 of 27 Turkish banks, found a negative impact of board tenure and board duality on the performance of the firm. These findings are inclined with the agency theory point of view that chairman of board should be independent, as CEO having greater power can misrepresent or manipulate earnings. On the bases of the aforementioned literature, keeping in mind the viewpoint of agency theory this study proposes that:

\section{H1e: There is a negative relation between CEO duality and EM.}

\section{Board Composition / Board Independence and Earning Management}

A major responsibility of the board of director is to provide a higher quality of disclosure on operational and financial reporting to its stakeholders and shareholders. Levitt (1998) reported that well corporate governance performed by boards of directors is an influencing factor on financial reporting that results in gaining the confidence of investor. Aligned with the agency theory, its board of directors responsibility theory to protect shareholder's interest by monitoring management. Furthermore, it is also expected that composition of the board may also influence a firms engagement in EM. He, Labelle, Piot, and Thorn- 
ton (2009) concluded a result based on US studies that one of the most effective deterrent factors of manipulated financial reporting is board independence. These results are consistent as independent directors have less likelihood of being used so they have strong encouragement to a higher quality of financial reporting. Independent board competes in the directors' labor market, they get incentives to keep and establish a reputation as a professional expert who looks for shareholder value and can effectively monitor manager in bulging it Fama and Jensen (1983).

There is a significant amount of literature exist on the board independence/board composition, more specifically, outside versus inside directors. Boards dominated by outside directors have considerably better control and monitoring over managers. Outside directors not only bring a better breadth of experience but they are more independent on the managers of the firm. The board composition can play a vital role in developing the interest of shareholders and managers. The requirement of structure for corporate governance in some countries like Nigeria is that the executives' directors should be less than the outside directors on the board, and non-executives directors should be appointed on the basis of competence and experiences and are composed of independent directors. As the directors outside of the firm have no interest regarding the shareholding, so to gain and maintain their own reputation, they try to put their efforts to enhance the value of the firm. The basic proposition regarding board composition is that if the board has maximum representation from the independent directors outside then it may affects the firm value positively which ultimately results in a lower EM.

Literature of CG revealed the board independence is considered as a proxy of transparent disclosure of financial reports. It is recommended by the researchers that in the composition of the board, the number of external members should be greater than owners. For the effective monitoring of activities, decisions and transparency board composition play a vital role (Patelli \& Prencipe, 2007; C. Chen \& Jaggi, 2000). Moreover there are a number of empirical evidences relating to the board composition and EM, documenting a direct relationship between the proportion of external directors and quality of financial reporting that ultimately constrict the issue of EM (Jaggi, Leung, \& Gul, 2009; Osma \& Noguer, 2007). So it can be proposed that:

H1f: There is a negative relationship between Boards independence and EM.

\section{Methodology}

The objective of the study is achieved by adopting a panel data analysis approach by using data of firms listed on Karachi Stock Exchange (KSE). From the 100 listed firms on KSE-100 index, 74 non-financial firms are chosen as sample. The data covers a time span of nine years from 2005 to 2013. Earnings management is calculated through discretionary accruals as a proxy by using the Modified Jones Model. The data was first tested for the assumptions of regression and later, correlation and Panel Regression analysis are applied for empirical findings

For the empirical testing, following is the regression model which is used: 


$$
\begin{array}{r}
E M=\alpha+\beta_{1} I N S O W N+\beta_{2} B O M E E T+\beta_{3} M A N O W N+\beta_{4} D A C C+\beta_{5} C E O D U A+ \\
\beta_{6} B O S I Z E+\beta_{7} B O I N D P+\epsilon
\end{array}
$$

Whereas, EM is the earning management, INSOWN is the institutional ownership, BOMEET is the ownership structure, MANOWN is managerial structure, DACC is board activity, CEODUA is the CEO duality, BOSIZE is board sixe and finally BOINDP is board independence, and $\epsilon$ denote as error term.

\section{Empirical Results}

\section{Correlation Analysis}

The correlation is used to determine the association between the independent and dependent variables. The results shown in Table 1 illustrate that correlation exist between proxies of corporate governance and EM. The results revealed a significantly negative relationship between INTOWN (-.428), MANOWN (-.1748), BOMEET (-.192), BOSIZE ($0.0293)$, BOINDP (-.456) and DACC. The correlations between OWNCON (0.0088) and CEODUA (.1046) showed a positive and significant association with DACC.

Table 1

Correlation analysis of Corporate Governance and Earnings Management

\begin{tabular}{lccccccc}
\hline & INSOWN & MANOWN & BOMEET & CEODUA & BOSIZE & BOINDP & DACC \\
\hline INSOWN & 1 & & & & & & \\
MANOWN & 0.3353 & 1 & & & & & \\
BOMEET & -0.0223 & -0.0105 & 1 & & & & \\
CEODUA & 0.1739 & 0.18410 & -0.1031 & 1 & & & \\
BOSIZE & -0.0241 & -0.2117 & 0.2154 & -0.1401 & 1 & & \\
BOINDP & 0.0338 & -0.1481 & 0.2579 & -0.3525 & 0.3821 & 1 & \\
DACC & -0.4280 & -0.1748 & -0.1920 & 0.1046 & -0.0293 & -0.4560 & 1 \\
\hline
\end{tabular}

\section{Regression Analysis}

In order to avoid spurious regression results, data was first tested for the assumptions of regression, i.e., multicollinearity and heteroscekedasticity. In order to ensure unbiased regression estimates, the independent variables in the model should be uncorrelated. In the presence of multicollinearity, regression estimates become biased and spurious. To check multicollinearity in the data, we used Variance Inflation Factor (VIF). If the values of VIF is greater than 10, it implies that the data has the problem of multicollinearity. The results of the VIF test are presented in table 2 below. 


\begin{tabular}{|c|c|c|}
\hline & VIF & 1/VIF \\
\hline BOINDP & 1.54 & 0.649 \\
\hline BOMEET & 1.51 & 0.662 \\
\hline BOSIZE & 1.48 & 0.676 \\
\hline MANOWN & 1.37 & 0.730 \\
\hline INSOWN & 1.21 & 0.826 \\
\hline
\end{tabular}

The results show that the values of VIF are lesser than the 10, hence our data do not have the problem of multicollinearity.

Ordinary Least Square regression requires the variance of residuals to be homogeneous or homoscedastic for adequate fitness of model. The assumption of homoscedasticity is checked by using the Breusch-Pagan/Cook-Weisberg test. The results in Table 3 showed the issue of heteroscedasticity in the data. In the presence of heteroskedasticity, the standard errors are biased which affects the t-stats and significance of the model. Therefore, we used the regression analysis with robust standard error as a remedy of heteroscedasticity in our data.

\begin{tabular}{lc} 
Table 3 & \\
Breusch-Pagan / Cook-Weisberg test for Heteroskedasticity \\
\hline$C h i^{2}(1)$ & 1863.53 \\
Prob $>c h i^{2}$ & 0.000 \\
\hline
\end{tabular}

Before estimating the regression model, we need to check the appropriate model between random effect and fixed effect. For this pupose, Hausman test is used (Kamran \& Shah, 2014). The null hypothesis of the test states that random effect model is appropriate. The results in Table 4 favor the use of the random effect model.

\begin{tabular}{|c|c|}
\hline \multicolumn{2}{|c|}{$\begin{array}{l}\text { Table } 4 \\
\text { Hausman Test }\end{array}$} \\
\hline$C h i^{2}(10)$ & 6.88 \\
\hline Prob $>c h i^{2}$ & 0.7367 \\
\hline
\end{tabular}

The result of random effect models is shown in Table 5. In this model INSOWN, MANOWN, BOSIZE, BOMEET, CEODUA, and BOINDP were regressed on DACC. Results showed that $\mathrm{R}$-square is .53 represent $53 \%$ variation in the model and significance of Wald $c h i^{2}\left(19.49^{* *}\right)$ shows that the statistical significance of the model. It was hypothesized that INSOWN has a negative and significant impact on DACC (H1a). Results show that INSOWN has a negative and significant impact on DACC $(\beta=-0.26 * * ; p<0.05)$ thus, supporting H1a. It was hypothesized that MANOWN has a negative and significant impact on DACC $(\mathrm{H} 1 \mathrm{~b})$. Results show that MAANOWN has a negative and significant impact on DACC $(\beta=-0.66 * * ; p<0.05)$ thus, supporting H1b. It was hypothesized that BOSIZE has a negative and significant impact on DACC (H1c). Results show that BOSIZE has a negative and significant impact on DACC $(\beta=-0.19 * * ; p<0.05)$ thus, supporting H1c. It was hypothesized that BOMEET has a negative and significant im- 
pact on DACC (H1d). Results show that BOMEET has a negative but not significant impact on DACC $(\beta=-0.79 ; p>0.05)$ thus, not in favor of H1d. It was hypothesized that CEODUA has a significantly positive impact on DACC $(\mathrm{H} 1 \mathrm{e})$. Results show that CEODUA has a significantly positive impact on DACC $(\beta=0.02 ; p<0.05)$ thus, supporting H1e. It was hypothesized that BOINDP has a negative and significant impact on DACC (H1f). Results show that BOINDP has a negative and significant impact on DACC $(\beta=-0.27 * * ; p<0.05)$ thus, supporting H1f.

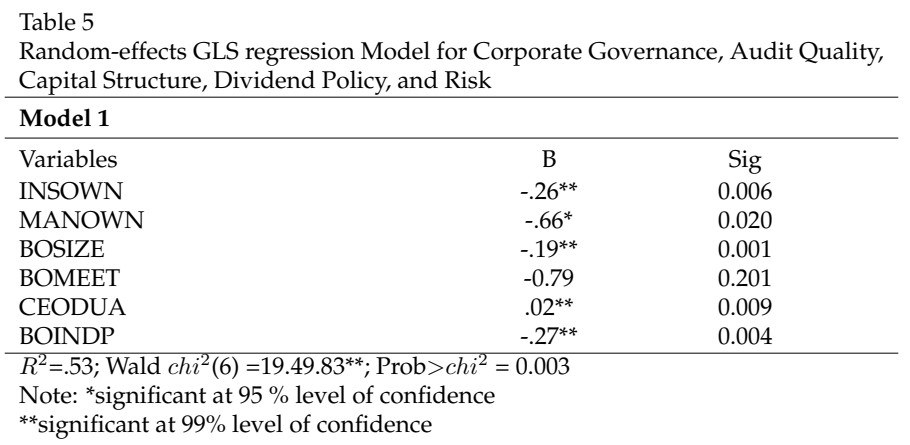

\section{Discussion}

In general, findings revealed that the indicators of corporate governance are significant predictors of EM and restricts the likelihood of EM practice of a firm. For Hypothesis H1a it is evident from the results that institutional ownership has a negative and significant impact on EM. The results are consistent with the study of Kamran and Shah (2014); Hassan and Ahmed (2012). So, this relationship reveals that institutional investors have sophisticated investment behavior and also have urge to collect information regarding the firm in which they intend to invest or have invested. Furthermore, they have an active monitoring role to reduce the opportunistic behavior. Abdallah, Hassan, and Mc Clelland (2015) documented that institutional ownership is an important indicator in Pakistan as institutional investors use their power to force managers for dividend payouts. Further, the study also found a negative and significant relationship between managerial ownership and EM practices. The results of this relationship are consistent with the study of Hassan and Ahmed (2012); Cornett, McNutt, and Tehranian (2009). Managerial ownership is one of the fundamental incentive to motivate managers to act actively for the value of the firm and ensure the quality reporting of earnings to attract investors. The shareholdings by managers encourage them to act as disciplining the mechanism and maximizing shareholder value. The results for the relationship of board size and EM practices showed board size as a significant and negative indicator of EM as proposed in hypothesis H1c. The results are in line with the studies of Kao and Chen (2004). As the board size increases, there is poorer communication and coordination among members of the board which result in inefficient monitoring and supervision of management. This communication and coordination gap provide space for managers to manipulate earnings for their 
own interest. The result for hypothesis H1d did not support the proposition and indicate an insignificant relationship between board activities and EM. However, these results are also consistent with some previous researches like Habbash (2010). A possible reason for this insignificant relationship is that organization in Pakistani settings are mostly family owned that may affect the independence of the board. Therefore, even a greater number of meetings may not restrict the earnings of management practices. The finding supports the proposition H1e that dual role of CEO appears as a barrier to the division between the control function and management. The chance of misrepresentation increases if a single person is responsible for the firms' financial as well as operating decisions (Jensen, 1993; Zaighum, 2014). Therefore, firms having the same person as CEO and chairman are more liable for lower financial reporting. It is because to achieve his own interest, CEO may manipulate the financial reporting. Findings of the study also support proposition H1f and are consistent with previous studies like Shah, Zafar, and Durrani (2009). It can be concluded that independent directors have less likelihood of being used so they have strong encouragement to a higher quality of financial reporting. Thus, the board independence is an effective deterrent factor of manipulated financial reporting and restrains EM practices.

\section{Conclusion and Policy Recommendations}

This study provides solid grounds and valuable insight for academicians who are interested in determinants of EM in developing countries as well as in emerging markets. In this research, theoretical model is developed on the basis of agency theory and existing literature of finance. The findings of our study concluded that efficient corporate governance practices allow the managers to evaluate the role of the monitoring systems and also help in development of the favorable perception of shareholders regarding the quality of available financial information. The availability of reliable and accurate information of corporate performance provides the basis for effective financial decision making to shareholders. The findings of the study are helpful to stock market participants and investors in the decision making process.

\section{Limitations and Future Recommendations}

Regardless of the useful findings of this research, here are some limitations of the study. The sample in this research consisted only the non-financial firms of listed firms of KSE Pakistan. So, the findings of this research can be generalized for non-financial firms only, as the governance rules are different for financial firms. The future studies may consider the financial and non-listed firms for further exploration of this phenomenon. Moreover, in this study corporate governance proxies are measured estimated from financial statements. Future studies can focus on the development of an index for corporate governance by considering the different clauses of the Pakistani Code of Corporate Governance (PCCG) that will be more helpful to access the effectiveness of code in restraining practices of EM. This study used an institutional ownership as a stock held by all institutions, 
breakup of institutional ownership into the non-financial and financial institutional ownership can also be considered for future studies. Further, financial institutional ownership can be separated into mutual funds, insurance companies, banks, and pension funds, to find out the unique role of each group of institutions. Future studies can also consider some other proxies like auditor tenure, family ownership and gearing ratio, cash dividend payment and systematic risk to measure their impact on EM. 


\section{References}

Abdallah, A. A.-N., Hassan, M. K., \& Mc Clelland, P. L. (2015). Islamic financial institutions, corporate governance, and corporate risk disclosure in Gulf cooperation council countries. Journal of Multinational Financial Management, 31, 63-82.

Adams, R. B., \& Ferreira, D. (2009). Women in the boardroom and their impact on governance and performance. Journal of Financial Economics, 94(2), 291-309.

Azeem, M., Hassan, M., \& Kouser, R. (2013). What causes pro-environmental action: Case of business graduates, Pakistan. World Applied Sciences Journal, 24(12), 1642-1650.

Bao, S. R., \& Lewellyn, K. B. (2017). Ownership structure and earnings management in emerging markets- An institutionalized agency perspective. International Business Review, 26(5), 828-838.

Barako, D. G., Hancock, P., \& Izan, H. (2006). Factors influencing voluntary corporate disclosure by Kenyan companies. Corporate Governance: An International Review, 14(2), 107-125.

Beasley, M. S. (1996). An empirical analysis of the relation between the board of director composition and financial statement fraud. Accounting Review, 14(2), 443-465.

Beneish, M. D. (2001). Earnings management: A perspective. Managerial Finance, 27(12), 3-17.

Berry, T. K., Fields, L. P., \& Wilkins, M. S. (2006). The interaction among multiple governance mechanisms in young newly public firms. Journal of Corporate Finance, 12(3), 449-466.

Braswell, M., \& Daniels, R. B. (2017). Alternative earnings management techniques: What audit committees and internal auditors should know. Journal of Corporate Accounting $\mathcal{E}$ Finance, 28(2), 45-54.

Bugshan, T. O. (2005). Corporate governance, earnings management, and the information content of accounting earnings: Theoretical model and empirical tests.

Bushee, B. J. (2001). Do institutional investors prefer near-term earnings over long-run value? Contemporary Accounting Research, 18(2), 207-246.

Chan, K. H., Lin, K. Z., \& Zhang, F. (2007). On the association between changes in corporate ownership and changes in auditor quality in a transitional economy. Journal of International Accounting Research, 6(1), 19-36.

Chekili, S. (2012). Impact of some governance mechanisms on earnings management: An empirical validation within the Tunisian market. Journal of Business Studies Quarterly, 3(3), 95.

Chen, C., \& Jaggi, B. (2000). Association between independent non-executive directors, family control and financial disclosures in Hong Kong. Journal of Accounting and Public Policy, 19(4-5), 285-310.

Chen, L., \& Zhang, L. (2007). Neoclassical factors (Tech. Rep.). Retrieved from https : / / doi.org/10.3386\%2Fw13282 doi: 10.3386/w13282

Claessens, S., Djankov, S., \& Xu, L. C. (2000). Corporate performance in the East Asian financial crisis. The World Bank Research Observer, 15(1), 23-46.

Coffee, J. C. (2002). Understanding enron: Its about the gatekeepers. Stupid, The Business Lawyer, 1403-1420. 
Cornett, M. M., McNutt, J. J., \& Tehranian, H. (2009). Corporate governance and earnings management at large US bank holding companies. Journal of Corporate finance, 15(4), 412-430.

De Andrés-Alonso, P., Cruz, N. M., \& Romero-Merino, M. E. (2006). The governance of nonprofit organizations: Empirical evidence from nongovernmental development organizations in Spain. Nonprofit and Voluntary Sector Quarterly, 35(4), 588-604.

Dechow, P. M., Sloan, R. G., \& Sweeney, A. P. (1996). Causes and consequences of earnings manipulation: An analysis of firms subject to enforcement actions by the sec. Contemporary Accounting Research, 13(1), 1-36.

Ebrahim, A. (2007). Earnings management and board activity: An additional evidence. Review of Accounting and Finance, 6(1), 42-58.

Fama, E. F., \& Jensen, M. C. (1983). Separation of ownership and control. The Journal of Law and Economics, 26(2), 301-325.

Gillan, S. L. (2006). Recent developments in corporate governance: An overview. Journal of Corporate Finance, 12(3), 381-402.

Gillian, S. L., \& Starks, L. T. (1998). Corporate governance and shareholder activism: The role of institutional investors (Tech. Rep.). Working paper, University of Texas.

Goodstein, J., Gautam, K., \& Boeker, W. (1994). The effects of board size and diversity on strategic change. Strategic Management Journal, 15(3), 241-250.

Gulzar, M. A. (2011). Corporate governance characteristics and earnings management: Empirical evidence from Chinese listed firms. International Journal of Accounting and Financial Reporting, 1(1), 133-151.

Habbash, M. (2010). The effectiveness of corporate governance and external audit on constraining earnings management practice in the UK (Unpublished doctoral dissertation). Durham University.

Hassan, S. U., \& Ahmed, A. (2012). Corporate governance, earnings management and financial performance: A case of Nigerian manufacturing firms. American International Journal of Contemporary Research, 2(7), 214-226.

He, L., Labelle, R., Piot, C., \& Thornton, D. (2009). Board monitoring, audit committee effectiveness, and financial reporting quality: Review and synthesis of empirical evidence. Journal of Forensic $\mathcal{E}$ Investigative Accounting, 1(2), 1-14.

Healy, P. M., \& Wahlen, J. M. (1999). A review of the earnings management literature and its implications for standard setting. Accounting Horizons, 13(4), 365-383.

Jaggi, B., Leung, S., \& Gul, F. (2009). Family control, board independence and earnings management: Evidence based on Hong Kong firms. Journal of Accounting and Public Policy, 28(4), 281-300.

Jensen, M. C. (1993). The modern industrial revolution, exit, and the failure of internal control systems. The Journal of Finance, 48(3), 831-880.

Jesus, S., \& Emma, G. (2013). Does corporate governance influence earnings management in latin American markets? Journal of Business Ethics, 10(6), 815-892.

Jones, T. M. (1991). Ethical decision making by individuals in organizations: An issuecontingent model. Academy of Management Review, 16(2), 366-395.

Kamran, K., \& Shah, A. (2014). The impact of corporate governance and ownership structure on earnings management practices: Evidence from listed companies in 
Pakistan. The Lahore Journal of Economics, 19(2), 27-70.

Kao, L., \& Chen, A. (2004). The effects of board characteristics on earnings management. Corporate Ownership \& Control, 1(3), 96-107.

Kaymak, T., \& Bektas, E. (2008). East meets west? board characteristics in an emerging market: Evidence from Turkish banks. Corporate Governance: An International Review, 16(6), 550-561.

Klein, A. (2002). Audit committee, board of director characteristics, and earnings management. Journal of Accounting and Economics, 33(3), 375-400.

Laksmana, I., Tietz, W., \& Yang, Y.-W. (2012). Compensation discussion and analysis (CD\&A): Readability and management obfuscation. Journal of Accounting and Public Policy, 31(2), 185-203.

Lefort, F., \& Walker, E. (2005). The effect of corporate governance practices on company market valuation and payout policy in Chile. Retrieved from SSRN:https://ssrn.com/abstract $=676710$.orhttp: / /dx.doi.org/ $10.2139 / \operatorname{ssrn} .676710$

Levitt, A. (1998). The numbers game. . The CPA Journal, 68(12), 14-19.

Lin, J. W., \& Hwang, M. I. (2010). Audit quality, corporate governance, and earnings management: A meta-analysis. International Journal of Auditing, 14(1), 57-77.

Lipton, M., \& Lorsch, J. W. (1992). A modest proposal for improved corporate governance. The Business Lawyer, 59-77.

Liu, Q., \& Lu, Z. J. (2007). Corporate governance and earnings management in the Chinese listed companies: A tunneling perspective. Journal of Corporate Finance, 13(5), 881906.

Monks, R. A. G., \& Minow, N. (Eds.). (2012). Corporate governance. John Wiley \& Sons, Inc.

Osma, B. G., \& Noguer, B. G.-d.-A. (2007). The effect of the board composition and its monitoring committees on earnings management: Evidence from Spain. Corporate Governance: An International Review, 15(6), 1413-1428.

Patelli, L., \& Prencipe, A. (2007). The relationship between voluntary disclosure and independent directors in the presence of a dominant shareholder. European Accounting Review, 16(1), 5-33.

Patton, M. Q. (1990). Qualitative evaluation and research methods. SAGE Publications, inc.

Peasnell, K. V., Pope, P. F., \& Young, S. (2005). Board monitoring and earnings management: Do outside directors influence abnormal accruals? Journal of Business Finance $\mathcal{E}$ Accounting, 32(7-8), 1311-1346.

Raza, S. A., \& Karim, M. Z. A. (2016). Do liquidity and financial leverage constrain the impact of firm size and dividend payouts on share price in emerging economy. Journal of Finance and Economics Research, 1(2), 73-88.

Sánchez-Ballesta, J. P., \& García-Meca, E. (2007). Ownership structure, discretionary accruals and the informativeness of earnings. Corporate Governance: An International Review, 15(4), 677-691.

Shah, S. Z. A., Zafar, N., \& Durrani, T. K. (2009). Board composition and earnings management: An empirical evidence from Pakistani listed companies. Middle Eastern Finance and Economics, 3(29), 30-44. 
Shleifer, A., \& Vishny, R. W. (1997). A survey of corporate governance. The Journal of Finance, 52(2), 737-783.

Stulz, R. (1988). Managerial control of voting rights: Financing policies and the market for corporate control. Journal of Financial Economics, 20, 25-54.

Swastika, D. L. T. (2013). Corporate governance, firm size, and earning management: Evidence in Indonesia stock exchange. Journal of Business and Management, 10(4), 77-82.

Teshima, N., \& Shuto, A. (2008). Managerial ownership and earnings management: Theory and empirical evidence from Japan. Journal of International Financial Management E Accounting, 19(2), 107-132.

Xie, B., Davidson III, W. N., \& DaDalt, P. J. (2003). Earnings management and corporate governance: The role of the board and the audit committee. Journal of Corporate Finance, 9(3), 295-316.

Yang, C. Y., Lai, H. N., \& Leing, T. B. (2008). Managerial ownership structure and earnings management. Journal of Financial Reporting and Accounting, 6(1), 35-53.

Yang, W. S., Chun, L. S., \& Shamsher, M. R. (2009). The effect of board structure and institutional ownership structure on earnings management. International Journal of Economics and Management, 3(2), 332-353.

Yermack, D. (1996). Higher market valuation of companies with a small board of directors. Journal of Financial Economics, 40(2), 185-211.

Yu, F. F. (2008). Analyst coverage and earnings management. Journal of Financial Economics, 88(2), 245-271.

Zahra, S. A., \& Pearce, J. A. (1989). Boards of directors and corporate financial performance: A review and integrative model. Journal of Management, 15(2), 291-334.

Zaighum, I. (2014). Impact of macroeconomic factors on non-financial firms stock returns: Evidence from sectorial study of KSE-100 index. Journal of Management Sciences, 1(1), 35-48.

Zhao, Y., Chen, K. H., Zhang, Y., \& Davis, M. (2012). Takeover protection and managerial myopia: Evidence from real earnings management. Journal of Accounting and Public Policy, 31(1), 109-135. 